\title{
Approaching the Prehistory of Norfolk Island
}

\author{
Atholl Anderson ${ }^{1}$ AND Peter White ${ }^{2}$ \\ ${ }^{1}$ Department of Archaeology \& Natural History, Research School of Pacific and Asian Studies, \\ Australian National University, Canberra ACT 0200, Australia \\ aja@coombs.anu.edu.au \\ ${ }^{2}$ Archaeology, University of Sydney, Sydney NSW 2006, Australia \\ Peter.White@antiquity.usyd.edu.au
}

\begin{abstract}
Norfolk Island, on the northeast edge of the Tasman Sea, is of volcanic origin and moderate height. A humid, forested subtropical landmass, it had a diverse range of natural resources, including some food plants such as Cyathea, forest birds such as pigeon and parrot species and substantial colonies of seabirds, notably boobies and procellariids. Its shoreline had few shellfish, but the coastal waters were rich in fish, of which Lethrinids were especially abundant.

The island had no inhabitants when discovered by Europeans in A.D. 1774. It was settled by them in A.D. 1788. From the eighteenth century discovery of feral bananas and then of stone adzes, knowledge of the prehistory of Norfolk Island has developed over a very long period. Collections of stone tools seemed predominantly East Polynesian in orientation, but Melanesian sources could not be ruled out. Research on fossil bone deposits established the antiquity of the human commensal Rattus exulans as about 800 B.P. but no prehistoric settlement site was known until one was discovered in 1995 at Emily Bay during the Norfolk Island Prehistory Project.
\end{abstract}

Anderson, Atholl, And Peter White, 2001a. Approaching the prehistory of Norfolk Island. In The Prehistoric Archaeology of Norfolk Island, Southwest Pacific, ed. Atholl Anderson and Peter White, pp. 1-9. Records of the Australian Museum, Supplement 27. Sydney: Australian Museum.

The primary aim of the Norfolk Island Prehistory Project (NIPP), which began in 1995, was to determine the fact, extent and nature of pre-European settlement in the Norfolk Island archipelago, within the context of some wider questions of regional prehistory. Norfolk Island was of particular interest because of its status as one of the Polynesian "mystery" islands, its very isolated situation at the western extremity of Polynesian colonization, yet its proximity to Melanesia, and because of its history of tantalising evidence indicating former settlement.

That was not immediately apparent at European discovery. Ten days out from New Caledonia, on the 10th October 1774, HMS Resolution came upon a new island. A brief exploration suggested that it was uninhabited and Captain James Cook "took posission of this Isle... and named it Norfolk Isle, in honour of that noble family." (Beaglehole, 1961: 565). An absence of indigenous people was confirmed when extensive exploration and European settlement began in 1788, but at the same time evidence began to emerge of former habitation (below) and Norfolk Island became one of those "isolated, mystery islands" of Polynesia, "which have traces of prehistoric settlement, but which had no inhabitants at European contact." (Bellwood 1978: 352).

These islands occur in two main groups, equatorial atolls and sub-tropical high islands, of which Norfolk Island is the most westerly and was before our research perhaps the most enigmatic. Located almost equidistant between New Caledonia and New Zealand, it was open to settlement from either or both sources (if not others). New Caledonia and New Zealand represent the extremes of culture history in 
Remote Oceania, the former occupied since the Lapita culture era about 3,000 years ago and the latter colonized by East Polynesians as late as 800-700 years ago (Anderson, 1991). In addition, the geographical potential was more than just theoretical, for artefacts of Melanesian and East Polynesian (including New Zealand) affinities had been recovered on Norfolk Island in quite substantial numbers from the time of first settlement until the twentieth century (Specht, 1984, 1993), all without any evidence recorded of a prehistoric settlement site. One of the first questions to be asked, therefore, was the source of the occupants and whether multiple origins had been involved. Linked to it were questions about settlement chronology, including whether there had been more than one phase of colonization.

The second question is the issue of the extent to which Norfolk Island was isolated during its prehistoric occupation. While some of the mystery islands, notably the Pitcairn group (Weisler, 1995), had evidently maintained external contacts for a time, others had no further contact with the outside world following initial colonization, e.g., the Auckland Islands (Anderson and O'Regan, 2000). Norfolk is one of the more isolated of Pacific islands, making links with any possible homeland difficult to maintain and if, as the surface collections suggested, the original colonists had come from within South Polynesia (Anderson, 2000), notably the Kermadecs and New Zealand, then isolation might have been compounded by relatively difficult voyaging conditions. In respect of this and the first question, clearly matters of chronology and the sourcing of archaeological materials would need to loom large in the project.

A third area of interest concerned human-environmental relationships. The significant impact of prehistoric colonists on the geomorphology, vegetation and faunas of Pacific islands, and reciprocal consequences for cultural behaviour, are now widely discussed (e.g., Kirch and Hunt, 1997). Norfolk Island is subtropical, with a relatively limited range of resources, and had, perhaps, a severely limited suite of cultigens in prehistory. These factors, in addition to isolation, may have rendered long-term habitation particularly difficult (Anderson, in press). Palaeoenvironmental investigations of sedimentary samples containing potential indications of a human presence were an integral part of the project. From pollen spectra especially, a record of vegetation change extending to either side of the period of human occupation was sought. Complementary data on fauna were anticipated from archaeological excavations, and to a lesser extent from investigation of natural bone deposits (Anderson, 1996) and landsnails (Neuweger, White and Ponder, this vol.).

The results of the NIPP are reported in this volume. Before turning to the specific evidence, however, it is useful to present an overview of the environment within which prehistoric habitation occurred and of the unusually long road by which a cultural prehistory of Norfolk Island has eventually been reached.

\section{The natural history of Norfolk Island}

The Norfolk Island archipelago consists of three islands: Norfolk Island (3,455 ha), and the much smaller Phillip Island and Nepean Island (Fig. 1). Situated at $29^{\circ} 2$ 'S and $167^{\circ} 56^{\prime} \mathrm{E}$ (coordinates for Norfolk Island), the archipelago is equably sub-tropical with average monthly maximum temperatures of $19-25^{\circ} \mathrm{C}$, and minimums of $13-19^{\circ} \mathrm{C}$. The climate is mild and humid with average rainfall of $1313 \mathrm{~mm}$.

Prior to any human occupation the islands were probably entirely forested. The first observations of the northern shore in Duncombe Bay, by Captain Cook, noted the similarity of the vegetation to that in New Zealand:

we found... the Flax plant, many other Plants and Trees common to that country was found here but the chief produce of the isle is Spruce Pines which grow here in vast abundance and to a vast size... Here are the same sorts of Pigions, Parrots and Parrokeets as in New Zealand, Rails and some small birds... (Beaglehole, 1961: 565, see also Hoare, 1974).

Johann Forster (Hoare, 1982: 668-670), another in the landing party, observed the abundance of fish and seabirds, especially boobies and shearwaters, while William Wales, who also went ashore (Beaglehole, 1961: 869), noted the coastal growth of flax (Phormium tenax) and the "cabbage tree" (which was clearly the Norfolk palm, Rhopalostylis baueri), and collected "wood-sorrel", "sow-thistle" and "samphire" from along the shore. Beaglehole (1961: 869) identifies these respectively as Oxalis sp. (O. corniculata according to Forster, below), Sonchus oleraceus and Apium prostratum.

Lieutenant King landed on the north coast of Norfolk Island in March 1788 and set about exploring. He found that the forest, heavily entangled with supplejack, was without any clearings and almost impenetrable, but had no ground cover. The birds were exceedingly tame, able to be knocked down with a stick. Pigeons, parrots and parrokeets were numerous. Soon after, he landed at what was to become Sydney Bay (Kingston), noting that "the shore, close to the beach, was covered with a long kind of iris [flax] within which was an impenetrable forest." (King cited in Hunter, 1793: 300). Turtle were soon discovered on the eastern beach (Turtle Bay, later Emily Bay), although there was no evidence of their nesting there. Rats (probably Rattus exulans) appeared, nibbling the shoots of maize in the first gardens on Kingston Common and, soon after, grub-worms which attacked the potatoes, and later caterpillars of armyworm which infested the wheat. The edibility (and suitability as pig-food) of the Cyathea tree-fern pith was established ("it tastes like a bad turnip") and "thick clusters" of fruiting "plantain or bananas" were described in the small valley which became Arthur's Vale (Hunter, 1793: 306-313).

On 19th March 1790, the Sirius supply vessel was wrecked in Sydney Bay. Its convict and military passengers, and its crew, brought the Norfolk Island settlement unexpectedly up to more than 500 people. Reduced rations were ordered. The people began to catch the nesting "Bird of Providence" (Providence petrel, Pterodroma solandri), found on Mount Pitt in large numbers. According to Captain John Hunter (1793: 182):

They were, at the end of May, as plentiful as if none had been caught, although for two months before had been not less taken than from two to three thousand birds every night; most of the females taken in May were with egg...

However, neither fowling generally, nor fishing, were as productive as had been hoped. The latter was frequently frustrated by continually heavy seas at the landing place: Hunter's records (1793: 199), showing that in the year 


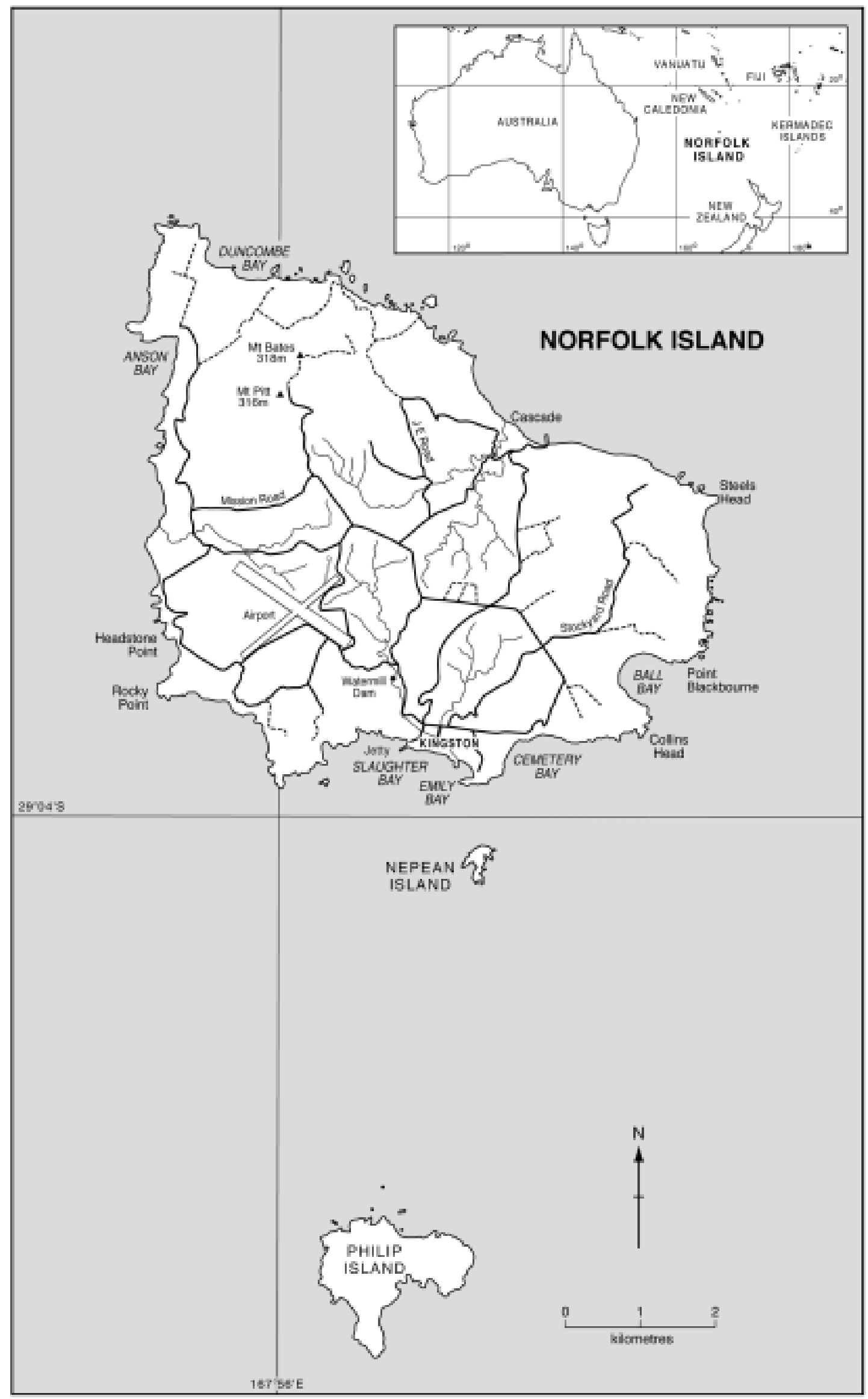

Figure 1. Norfolk, Nepean and Philip Islands. 
March 1790-February 1791, landings and launchings of boats were possible on only 178 days (54\%), with longer records (1788-1791) indicating an average of 64\% (Hicks, 1988: 162).

Leaving the island in March 1790, Lieutenant King summarized his observations. It was very heavily forested, the soil was deep and fertile, the streams contained fine eels (these were both long-finned and short-finned Anguilla spp., according to Christian, 1985), cabbage palm and flax were abundant, and the seas abounded with fish, notably "snapper" weighing four to eight pounds.

Out of these early records, and later investigations, it is possible to describe the general basis of the Norfolk Island archipelago's natural history considered largely from the point of view of its interest to prehistoric settlers.

Although described as high islands in the cultural sense, the topography of the three islands is not so spectacular as that of many other volcanic islands of East Polynesia. Nepean Island is low, but the others are hilly, rising to about $320 \mathrm{~m}$ in Mounts Pitt and Bates on Norfolk Island (Fig. 2), these being the remnants of former volcanic vents, 2.3 to 3 million years old. Norfolk Island is composed primarily of basaltic lava, often deeply-weathered, amongst which are flows of fine-grained material which is very suitable for flaking into implements. Phillip Island rises to $280 \mathrm{~m}$ and consists equally of basaltic lavas and tuffs. On the southern side of Norfolk Island, and forming Nepean Island, are thick deposits of calcarenite, a cemented, cross-bedded, aeolianite which arose from windblown calcareous material during the lowered sea levels of the late Pleistocene. Upon it are developed dunes of carbonate sands (Veevers, 1976; Jones and McDougall, 1973).

On fertile, alkaline clay soils which occur everywhere except upon the calcarenite and sand at Kingston (Hutton and Stephens, 1956) were distributed several forest communities. On the lower ground and ridges was Norfolk pine (Araucaria heterophylla) forest rising above mixed hardwood forest and shrubs. On the higher areas was mixed hardwood forest, including Maple (Elaeodendron curtipendulum), Ironwood (Nestigis apetala), Beech (Rapanea crassifolia) and Bloodwood (Baloghia inophyllum), with Cyathea spp. ferns, Pepper tree (Macropiper excelsium) and other shrubs beneath, all tangled with climbers and vines, some prickly. In some hardwood forests, the Norfolk palm (Rhopalostylis baueri [Hook f.]) was dominant, and along gullies it occurred in association with tree ferns, Cyathea brownii and $C$. australis. Flax often formed a coastal fringe. There were 200 Norfolk pines on Nepean Island, and about 150 amongst Cyperus lucidus reeds and low forest on Philip Island (Hicks, 1988).

The vegetation of Norfolk Island contained a number of useful plants. Of food sources, in addition to the shoreline herbs (above), there was the Norfolk palm with its edible "heart" of leaves, the rhizomes of the King fern (Marattia salicina) (Jurd, 1987), the pith of Cyathea spp. palms, roots of the Norfolk Island ti (Cordyline obtecta), and Hibiscus sp., and a number of fruits (Pepper-tree and Mountain rush, Freycinetia baueriana, amongst others). The flax especially, but some other plants, such as Kurrajong (Wickstroemia australis), provided valuable fibres for cordage and rope, and the Cyperus rush was used historically for making baskets (Hicks, 1988).

Norfolk Island was and is a seasonal destination or way station for many migratory birds, including ducks, egrets, coots, and numerous taxa of shore and wading birds. Of its endemic species or subspecies, the larger kinds noted by early Europeans have become extinct (Schodde et al., 1983). These were the Norfolk Island Ground Dove (Gallicolumba norfolciensis), the parrot or Norfolk Island Kaka (Nestor productus) and the Norfolk Island subspecies of the New Zealand Pigeon (Hemiphaga novaeseelandiae spadicea). Other native land birds which became extinct in the European era are the Long-tailed Triller (Lalage leucopyga leucopyga) and Norfolk Island Starling (Aplonis fusca fusca). Surviving, although rare, are the Boobook Owl (Ninox undulata), two species of White-eye (Zosterops spp.), Red-fronted Parakeet (Cyanoramphus novaezelandiae cookii), Grey-headed Blackbird (Turdus poliocephalus poliocephalus), Scarlet Robin (Petroica multicolor multicolor), Golden Whistler (Pachycephala pectoralis xanthoprota), Grey Fantail (Rhipidura fuliginosa pelzelni), and Grey Gerygone (Gerygone igata modesta). There were other land birds breeding on the island, at least in the late eighteenth century, including the Shining bronzeCuckoo (Chrysococcyx lucidus lucidus), Sacred Kingfisher (Halcyon sancta norfolkiensis) and a "hawk", which was probably the Australian Kestrel (Falco cenchroides cenchroides).

In addition to birds, there were very few terrestrial vertebrates (Hicks, 1988). These included two bats (Norfolk Island free-tail bat, Tadarida norfolkensis; Gould's wattled bat, Chalinolobus gouldii), a gecko (Phyllodactylus guentheri) and a skink (Leiolopisma lichenigerum). The small Pacific rat, Rattus exulans, had clearly been introduced by about 800 years ago (Rich et al., 1983).

Of the seabirds, the Providence Petrel (above) became locally extinct under European hunting which, in the winter of 1790 alone, took more than 172,000 birds, many of them females in egg (Hicks, 1988: 168); the species was no longer viable as a resource by 1792 (Fletcher, 1975: 196). Other seabirds which may have become locally extinct (Meredith, 1991) are Pycroft's Petrel (Pterodroma pycrofti) and the White-faced Storm Petrel (Pterodroma marina), but the systematic status of Sula tasmani is doubtful. However, most breeding or probable breeding species survived and they include: Masked Booby (Sula dactylatra personata), Australasian Gannet (Morus serrator), Black-winged Petrel (Pterodroma nigripennis), Wedge-tailed Shearwater (Puffinus pacificus), Little Shearwater (Puffinus assimilis), Red-tailed Tropicbird (Phaethon rubricauda roseotincta), Sooty Tern (Sterna fuscata serrata), Common Noddy (Anous stolidus pileatus), Black Noddy (Anous minutus minutus), Grey Ternlet (Procelsterna albivittata albivittata), and White Tern (Gygis alba royana) (Rich et al., 1983).

In the marine environment, the early European reports of numerous whales, dolphins and turtles hint at the former richness of the potential resources. The turtle was probably the Green Turtle (Chelonia mydas), still seen in local waters, which was found in Emily Bay and which still occurred as large shoals from time to time into the nineteenth century, as reported by Ensign Best in 1839 (Taylor, 1966: 201).

The Norfolk Island fish are, by diversity, largely tropical, but by abundance largely subtropical, especially amongst the inshore taxa. Survey of the Kingston lagoon (Ivanovici, 1988) and other records (Francis, 1993) show that amongst the more abundant species are the Orange Wrasse 


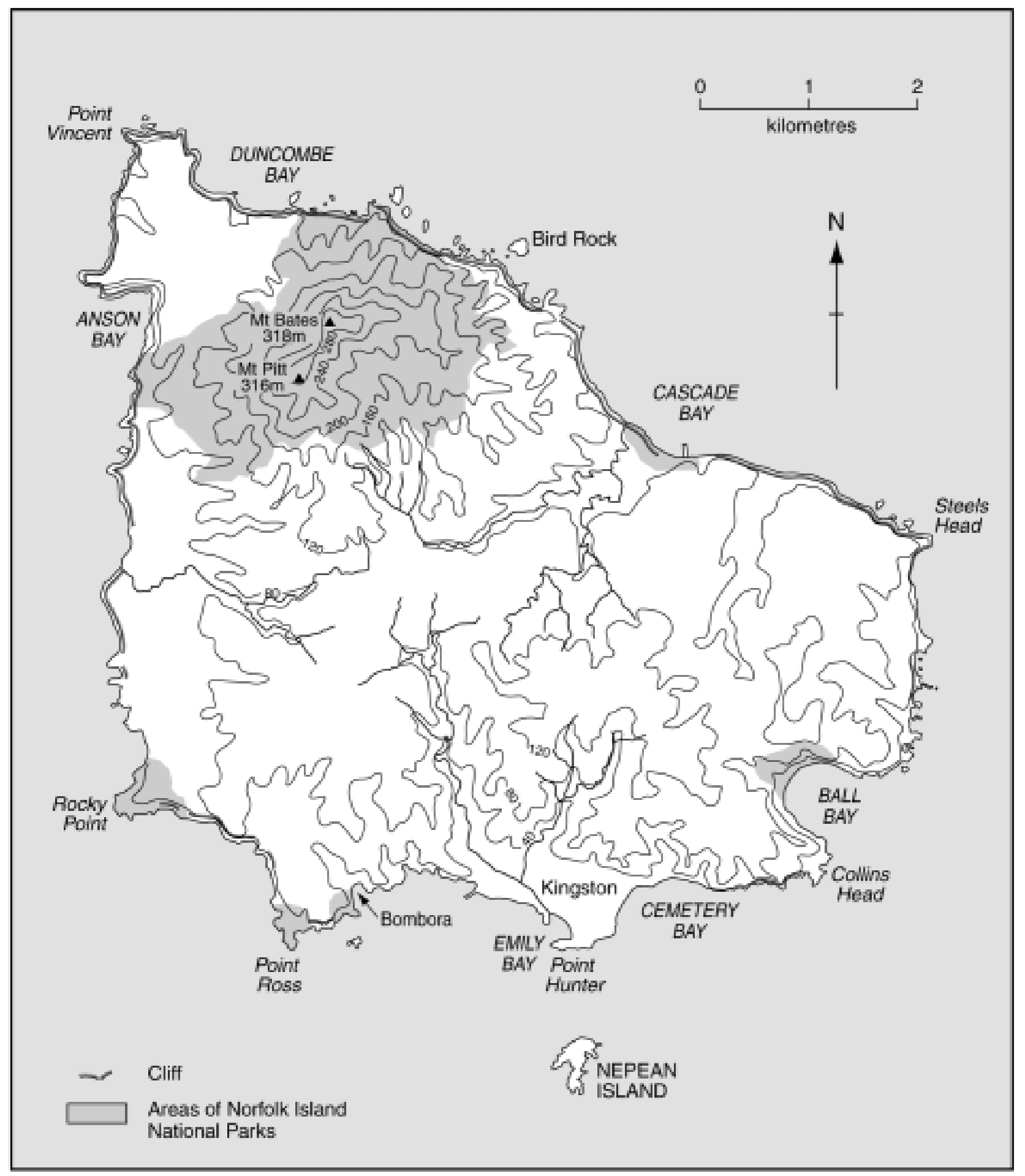

Figure 2. Norfolk Island, showing major peaks and coastal features. 
(Pseudolabrus lutescens), Red Snapper (Trachypoma macracanthus), Demoiselle (Chromis dispilus), Nanwhi (Kyphosus spp.) and One-spot Puller (Chromis hypsilepsis). These, however, are small fish (12-30 cm maximum length), so the main target species were more likely to be those sought in recent times, of which the Trumpeter or Sweetlip (Lethrinus miniatus, or L. chrysostomus) is among the largest, most prized and heavily fished (Hicks, 1988). Others are the various Serranids, including the Black-tipped Rock Cod (Epinephelus fasciatus) and Groper or Black rock cod (Epinephelus damelii), the Silver Bream (Chrysophrys auratus), Trevally (Pseudocaranx spp.) and Yellowtail kingfish (Seriola lalandi). In addition, there are various large species which, though less sought after today, were probably caught regularly and consumed by Polynesians: the Doubleheader (Coris bulbifrons), Painted Morwong (Cheilodactylus ephippium), Girdled rock cod (Acanthistius cinctus), Bucket fish (Scorpaenids) and various rays and sharks of which the Galapagos shark (Carcharhinus galapagensis) is one of the more common (Ivanovici, 1988; Coleman, 1991).

There are large shore crabs, notably Leptograpsus variegatus, and one crayfish, the Shovel-nosed cray (Scyllarides sp.). Various species of sea-urchins are abundant, especially Heliocidaris tuberculata in pools and shallows (Coleman, 1991). Of shellfish in the edible size range, Norfolk Island is noticeably deficient. Pelecypods are scarce and the only common gastropod species is the small upper-shore Hi-hi, Nerita atramentosa.

From the perspective of prehistoric colonists the Norfolk Island archipelago offered substantial resources of fish and seabirds, but it was otherwise rather deficient in subsistence items which might have been expected by tropical discoverers. The slim array of indigenous food plants contained neither pandanus nor coconut, there were few forest birds and no land crabs of economic size, and shellfish which generally formed a staple item of Pacific island diets were particularly scarce.

\section{Discovery of prehistoric habitation}

William Wales had concluded of Norfolk Island in 1774 that, "we saw no Inhabitants nor the least reason to believe it had ever been trod by Human feet before." (Beaglehole, 1961: 869). Yet his own plant collection possibly held a clue to earlier habitation: Sonchus oleraceus, the sow thistle, was found abundantly in New Zealand by Cook's first expedition in 1769-1771, as also was Apium prostratum, or Maori celery, both eaten by Maori and valued by Cook as soup and salad plants and as antiscorbutics (Crowe, 1981). Amongst these, and other weeds and succulents recorded by Forster, there may be some plants which arrived with prehistoric settlers.

The early European settlers did not draw any implication of prior habitation from the existence of small rats which attacked their crops, but they saw immediately the significance of finding bananas growing wild. Collins, writing in 1798 (Fletcher, 1975: 153), says that King had thought they suggested earlier habitation, from their occurring "in regular rows", although King does not make this remark in his journal, and the fact of their existence was in any case sufficient. Later, Maiden (1904: 723-724), the Government Botanist of New South Wales, doubted the identification of plantain as banana and suggested that it was actually taro, but the description seems sufficiently clear and King was more than once at pains to distinguish his introduced "Brazil" or "Rio Janeiro" plantains from the discovered variety (e.g., Hunter 1793: 317).

Even so, the existence of bananas planted in Arthur's Vale (Fig. 3) before the arrival of the European colonists, does not unequivocally support the inference of prehistoric settlement. It is possible that the bananas had been introduced to Norfolk Island by Pacific voyagers between 1774 and 1788, in which case the various accounts of canoe wreckage found on Norfolk Island could be more significant than is generally assumed. In September 1788, King (Hunter, 1793: 331) linked catching a turtle with a puncture wound in its back to the finding in Ball Bay of some canoe wreckage which included a wooden image of human form and a fresh coconut, and surmised the existence of undiscovered land close to the eastward. Communicated to Governor Phillip, this news was passed on (Phillip to Sydney, 28 September, 16 November 1788, in Britton, 1892: 187,211 ) initially as "two canoes... on the rocks, probably driven there from New Zealand" and later as "remains of two or three canoes" and, not necessarily associated with these, a piece of wood which appeared to have been not long in the water and was "said to resemble the handle of a flyflap" as made in Tonga. Later description (Phillip to Sydney 12 February 1790, in Britton, 1892: 296), separated the coconut from "parts of two canoes, which answer the description given of the canoes of New Zealand... and a wooden figure (very rudely carved)" of a kind found in Tonga. King also found a fresh coconut and remains of a canoe in Anson Bay (Hunter, 1793: 345). Whether any of these finds had been originally associated is uncertain, but it is possible that part of the canoe wreckage was the remains of a late eighteenth century landfall during which bananas were planted but then abandoned as the people died or managed to depart.

In any event, if the coastal finds including the bananas were suggestive of earlier contact, it seems to have been the period of major expansion inland, under the energetic direction of Major Ross, who had charge of the colony March 1790 to November 1791 in Commandant King's absence, which turned up the first direct evidence. Notice of this arrived in letters brought to Sydney by the Salamander in October 1791, and from which it seems King advised Joseph Banks, that "Some Stone Axes, Chizzles and other tools have been found under ground some depth in the interior part of Norfolk Island." (King to Banks 25th October 1791 in Specht, 1984: 12). The original letters are discussed by Collins (Fletcher, 1975: 153), who notes that the artefacts were "found in turning up some ground in the interior". It is an intriguing possibility that the ground in question was a 100 acre pre-European opening in the forest (the only one ever found), overgrown with vines, which Ross named Charlottefield and began preparing for cultivation in June 1790 (Ross, 1791). This area to the west of Mount Pitt was, possibly, the site of a prehistoric clearing. Development of it continued through 1790 and 1791 with the construction of a new village, Queenborough (Wright, 1988: 114).

The whereabouts of the stone tools reported by King are unknown, but it is possibly one of them, a handsome example of a tanged, quadrangular cross-sectioned adze of typical early East Polynesian form, which was painted 


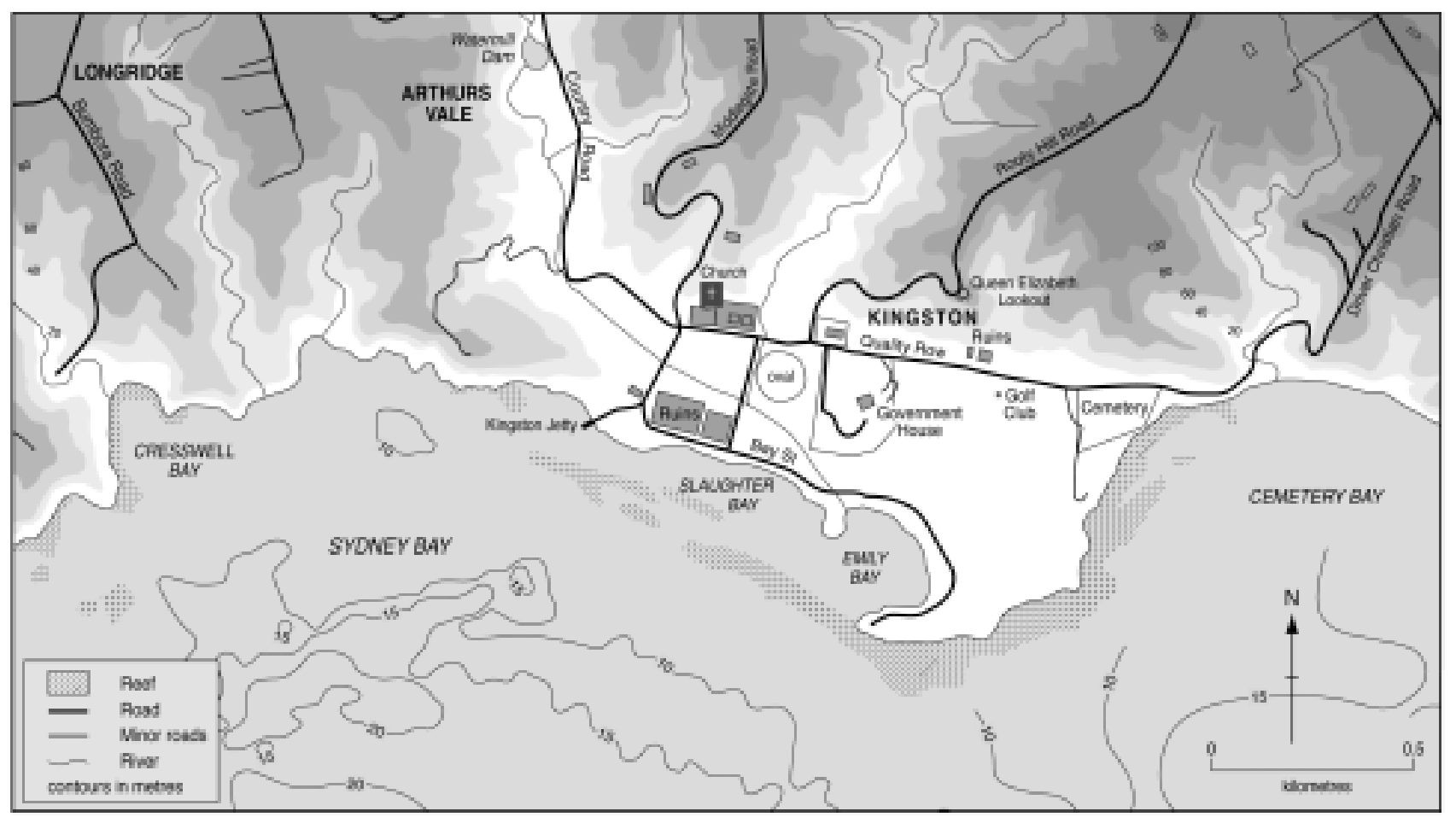

Figure 3. Arthur's Vale and Kingston areas.

between 1792 and 1794 in Sydney by Thomas Watling (Nobbs, 1988: vii, Specht, 1993: 147). At least one of the adzes was kept by King and shown to the two Northland Maori (Tuki and Huru) who had been brought to Norfolk Island to teach the working of flax; "they recognized it with extreme joy for an etoki [adze] of Eaheinomawe [E he ika no Maui, the fish of Maui, a traditional name for the North Island of New Zealand]." King then summarized his evidence; "[is] not this circumstance with that of the banana trees and canoe, a feasible proof of the island having been formerly inhabited or having made a part of New Zealand... “(King, 24th May 1793, in McCarthy, 1934: 267).

There is no known record of further discoveries of artefacts or of any other potentially prehistoric remains between the late eighteenth and early twentieth centuries, although it is almost inconceivable that none were made. The modern record begins with Thorpe's (1929) description of an adze found at Emily Bay by Harold Rabone whose recovery of material was described later by McCarthy (1934). He says that Rabone found in the sand dunes "a number of small adzes in process of being fashioned. With them were several hundred flakes that had been chipped off in the shaping of the adzes." The New Zealand ethnologist, Skinner, reviewed the material given to McCarthy and declared it to be characteristically Polynesian.

The history of later finds is described and analysed in detail by Specht $(1984,1993)$. He examined all the accessible material in museum (except Norfolk Island Museum) and private collections, combining stylistic with selected material analyses based upon petrological examination. He divided the implements into four groups. Group I consisted of two Australian tools, to which can be added one from the wreck of the Sirius (McBryde and Watchman, 1993; Stanbury, 1994). Group II consisted of two axe blades of Melanesian type (Specht, 1984), to which can be added a fragment of Trochus shell armband from the lagoon at Slaughter Bay and a large Tridacna shell blade found in sand at Cemetery Bay (Specht, 1993 and see Anderson, 1996). There are other probable Melanesian artefacts in the Norfolk Island Museum collection (uncatalogued when recorded and drawn by Anderson in 1995). Leaving aside a large triangular blade, donated by a Mr Watt, whose collection was gathered from around the Pacific, there is another donated lenticular cross-sectioned blade, and a pearl shell lure shank of Melanesian form found on the surface near the wharf in 1993 by Mr George Anderson. One possible source of Melanesian artefacts is the students from several Melanesian islands brought for training to the Melanesian Mission school on Norfolk Island. When it opened in 1866, indigenous artefacts were still commonly used, so the existence of such material on Norfolk Island need not necessarily be attributed to prehistoric visitors.

Groups III and IV comprised 30 pieces of Polynesian type, 25 of them in basalt and the remainder of volcanic or metamorphic silt and sandstones (Specht, 1984: 28). To them can be added six adzes described by Specht (1993), nine more basalt adzes and preforms in the Norfolk Island collection, all from Emily Bay or Slaughter Bay, a Duff, 1977 Type 2a basalt adze recovered in 1995 by Nicolai (below), and a Duff, 1977 Type 3 basalt adze found by Bob Tofts at Slaughter Bay in March 1996. The later finds add weight to Specht's (1984) original conclusions about the East Polynesian origin of this material, its particular similarity to the Raoul Island collections, and its associations with the Emily and Slaughter Bay area. The non-basalt pieces (Group IV) were mainly of Duff, 1977 Type $2 b$ form and in materials indicative of South Island New Zealand origin. They do not come from the Kingston beaches and may have either a late prehistoric origin separate to the 
Group III material or be European-era introductions.

Specht $(1978,1984)$ led an Australian Museum archaeological expedition to Norfolk Island in 1976. This surveyed the entire coastline and parts of the interior for archaeological sites. One mound and five other places inland were test-pitted, without uncovering anything of prehistoric archaeological interest (Specht, 1984: 10-11). On the coast, three test pits were excavated at Cascade without result. At Slaughter Bay a test square $\left(1 \mathrm{~m}^{2}\right.$ Specht [1978: 220] says two test pits at this point) was excavated to $2.8 \mathrm{~m}$ depth on the beach side of the seawall but it encountered no material of pre-European provenance. At Emily Bay, "several test pits were excavated at the western edge of the quarry cuttings into the dune" (Specht, 1984: 9), again without result and Specht (1978: 220) suggested that the Rabone adze had possibly come from Slaughter Bay. The test pits must have been very close to the edge of the prehistoric site which, as we now know it, lies in older dunes immediately beside the former sand quarry.

Attention then became focussed upon the fossil bone and landsnail deposits in the Kingston dunes. The Royal Australian Ornithological Union held its annual congress on the island in 1978, during which Davidson and Rich, following up some earlier explorations by Davidson, excavated on Nepean Island and at Slaughter Bay, Emily Bay and particularly Cemetery Bay (Rich et al., 1983). This research, continued by Orth (1980) and then Meredith (1985, 1991; Meredith et al., 1985), produced some results with archaeologically interesting implications. At Cemetery Bay and Emily Bay there were layers which contained fossil bird bones but also rat (Rattus exulans) bone and considerable charcoal, the latter dated at Cemetery Bay to the period 715-450 B.P. (Anderson, Higham and Wallace, this vol., see also Meredith et al., 1985: 306). Excavations of historical remains in the Pier area at Kingston also encountered lower deposits of charcoal and bird bone which Varman (1993: 15) suggests may be of prehistoric origin.

When sand mining operations expanded at Cemetery Bay in 1989, it therefore made sense to the Norfolk Island Government to have these deposits appraised by archaeologists, and several reports were commissioned. Varman's (1990) observations suggested that the charcoal-enriched level at Cemetery Bay had resulted from a single major event, such as forest clearance, with ash and charcoal then becoming swept or carried into bird burrows and rootholes. There were also heat-affected bird bones, perhaps of chicks or others caught in the fire, and a piece of basalt which Varman (1990: 14) took to be part of an adze, but which Specht (1993: 150) inspected and regards as dubious. Monitoring sand mining in the same area, Packard (1990) recorded further outcrops of the charcoal-enriched horizon, including remains of a burnt tree stump. The large shell adze referred to above and found in the same area is not clearly associated with any pre-European level (Anderson, 1996). To summarize, we suggest the Cemetery Bay evidence reflects less direct habitation than early forest clearance associated with it, but there might have been a settlement in the near vicinity.

The long record of artefactual discoveries, the stratigraphic evidence of a charcoal-enriched layer dated to about $800-700$ B.P. at Cemetery Bay, and the association of it with introduced rat bones, all added up to a fairly convincing suggestion of prehistoric settlement. All that was missing to confirm the case was a settlement site, and this finally came to light in December 1995. The investigations of it are described by Anderson, Smith and White (this vol.) and it provided most of the material on which the remainder of this volume is based.

\section{References}

Anderson, A.J., 1991. The chronology of colonization in New Zealand. Antiquity 65: 767-795.

Anderson, A.J., 1996. Discovery of a prehistoric habitation site on Norfolk Island. Journal of the Polynesian Society 105: 479486.

Anderson, A.J., 2000. The advent chronology of south Polynesia. In Essays in Honour of Arne Skjølsvold, 75 Years, ed. P. Wallin and H. Martinsson-Wallin. Occasional Papers of the Kon-Tiki Museum 5: 73-82.

Anderson, A.J., in press. No meat on that beautiful shore: the prehistoric abandonment of subtropical Polynesian islands. In Zooarchaeology of Oceanic Coasts and Islands, ed. A.J. Anderson and B.F. Leach. International Journal of Osteoarchaeology.

Anderson, A.J., and G. O'Regan, 2000. To the final shore: prehistoric colonisation of the subantarctic islands in south Polynesia. In Australian Archaeologist: Collected Papers in Honour of Jim Allen, ed. A. Anderson and T. Murray, pp. 440454. Canberra: Coombs Academic Press, Australian National University.

Beaglehole, J.C., 1961. The Journals of Captain James Cook on his Voyages of Discovery, Volume II. The Voyage of the Resolution and Adventure 1772-1775. Cambridge: Hakluyt Society.

Bellwood, P., 1978. Man's Conquest of the Pacific: The prehistory of Southeast Asia and Oceania. Auckland: Collins.

Britton, A., ed., 1892. Historical Records of New South Wales, Volume I, Part 2, Phillip 1783-1792. Sydney: Government Printer.

Christian, M., 1985. Two freshwater eels in Norfolk waters. Norfolk Island Nature Notes 1: 83.

Coleman, N., 1991. The Nature of Norfolk Island. Rochedale South: Sea Australia Resource Centre.

Crowe, A., 1981. A Field Guide to the Native Edible Plants of New Zealand. Auckland: Collins.

Duff, R.S., 1977. The Moa-hunter Period of Maori Culture. 3rd edn. Wellington: Government Printer.

Fletcher, B.H., ed., 1975. D. Collins. An Account of the English Colony in New South Wales, volume I (1798), volume II (1802). Sydney: Reed.

Francis, M.P., 1993. Checklist of the coastal fishes of Lord Howe, Norfolk, and Kermadec Islands, southwest Pacific Ocean. Pacific Science 47: 136-170.

Hicks, J., 1988. The natural history of Norfolk Island. In Norfolk Island and its First Settlement, 1788-1814, ed. R. Nobbs, pp. 159-172. Sydney: Library of Australian History.

Hoare, M., 1974. The Discovery of Norfolk Island. Canberra: Australian Government Publishing Service.

Hoare, M.E., 1982. The Resolution Journal of Johann Reinhold Forster 1772-1775, volume IV. London: Hakluyt Society.

Hunter, J., 1793. An Historical Journal of the Transactions at Port Jackson and Norfolk Island. Australiana Facsimile Editions. No. 148 (1968). Adelaide: Libraries Board of South Australia.

Hutton, J.T., and C.G. Stephens, 1956. The paleopedology of Norfolk Island. Journal of Soil Science 7: 255-267.

Ivanovici, A.M., 1988. Emily Bay and Slaughter Bay, Norfolk Island: Resources and Options for Management. Unpublished report to the Australian National Parks \& Wildlife Service, Canberra. 
Jones, J.G., and I. McDougall, 1973. Geological History of Norfolk and Phillip Islands, Southwest Pacific Ocean. Journal of the Geological Society of Australia 20: 239-254.

Jurd, G., 1987. The King fern (Marattia salicina). Norfolk Island Nature Notes 3: 215-216.

Kirch, P.V., and T.L. Hunt, 1997. Historical Ecology in the Pacific Islands: Prehistoric Environmental and Landscape change. New haven, Yale University Press.

Maiden, J.H., 1904. The flora of Norfolk Island. Proceedings of the Linnean Society of New South Wales 28: 692-785.

McBryde, I., and A. Watchman, 1993. “... lost in the Sirius...?” Consideration of the provenance of the hatchet head recovered from the Sirius wreck site, Norfolk Island. Records of the Australian Museum, Supplement 17: 129-143.

McCarthy, F.D., 1934. Norfolk Island: additional evidence of a former native occupation. Journal of the Polynesian Society 43: 267-270.

Meredith, C., 1985. The Vertebrate Fossil Fauna of Norfolk Island, and the Phylogeny of the Genus Pterodroma. Unpublished PhD thesis, Zoology Department, Monash University, Melbourne.

Meredith, C., 1991. Vertebrate fossil faunas from islands in Australasia and the southwest Pacific. In Vertebrate Palaeontology of Australasia, ed. P. Vickers-Rich, J.M. Monaghan, R.F. Baird and T.H. Rich, pp. 1345-1382. Melbourne: Monash University Publications Committee.

Meredith, C.W., J.R. Specht and P.V. Rich, 1985. A minimum date for Polynesian visitation to Norfolk Island, Southwest Pacific, from faunal evidence. Search 16: 304-306.

Nobbs, R., ed., 1988. Norfolk Island and its First Settlement, 17881814. Sydney: Library of Australian History.

Orth, K., 1980. A Study of the Geology, Palaeontology, and Biogeography of Nepean Island and the Kingston Area of Norfolk Island, Southwest Pacific. Project for Geology 301. Melbourne: Monash University.

Packard, P., 1990. Archaeological Supervision of Sand Extraction at Site 1, Cemetery Bay, KAVHA, Norfolk Island. Unpublished interim report to the Norfolk Island Government.

Rich, P., G. van Tets, K. Orth, C. Meredith and P. Davidson, 1983. Prehistory of the Norfolk Island biota. In A Review of Norfolk Island Birds: Past and Present, ed. R. Schodde, P. Fullagar and N. Hermes, pp. 7-29. Australian National Parks \& Wildlife Service, Special Publication 8. Canberra: Australian National
Parks \& Wildlife Service.

Ross, R., 1791. Ross to Philip, 11 February 1971, ed. A. Britton, 1892. Historical Records of New South Wales I (2): 442-444.

Schodde, R., P. Fullagar and N. Hermes, 1983. A Review of Norfolk Island Birds: Past and Present. Australian National Parks \& Wildlife Service, Special Publication 8. Canberra: Australian National Parks \& Wildlife Service.

Specht, J., 1978. The early mystery of Norfolk Island. Australian Natural History 19: 218-223.

Specht, J., 1984. The Prehistoric Archaeology of Norfolk Island. Pacific Anthropological Records 34. Honolulu: Bernice P. Bishop Museum.

Specht, J., 1993. Additional evidence for pre-1788 visits by Pacific Islanders to Norfolk Island, South-west Pacific. Records of the Australian Museum, Supplement 17: 145-157.

Stanbury, M., 1994. HMS Sirius 1790: an illustrated catalogue of artefacts recovered from the wreck site at Norfolk Island. Australian Institute of Maritime Archaeology, Special Publication 7.

Taylor, N.M., 1966. The Journal of Ensign Best, 1837-1843. Wellington: Government Printer.

Thorpe, W.W., 1929. Evidence of Polynesian culture in Australia and Norfolk Island. Journal of the Polynesian Society 38: 123-126.

Varman, R.V.J., 1990. Cemetery Bay water assurance scheme, Quarry Site 1, Archaeological report. Unpublished report prepared for the Norfolk Island Government.

Varman, R.V.J., 1993. Pier Area, report on archaeological excavations, September-December 1983 and April-May 1984, Key to site and excavated material. KAVHA Archaeological report 7, part 5, Department of Administrative Services, New South Wales.

Veevers, J.J., 1976. The modern coastal sedimentary rock complex of Norfolk and Nepean islands. In A Groundwater Investigation of Norfolk Island, ed. R.S. Abell, pp. 65-67. Bureau of Mineral Resources, Geological and Geophysics Record 1976/62.

Weisler, M.I., 1995. Henderson Island prehistory: colonization and extinction on a remote Polynesian island. Biological Journal of the Linnean Society 56: 377-404.

Wright, R., 1988. Land Usage. In Norfolk Island and its First Settlement, 1788-1814, ed. R. Nobbs, pp. 112-125. Sydney: Library of Australian History. 

Full-text PDF of each one of the works in this volume are available at the following links :

Anderson and White, vol. eds, 2001, Rec. Aust. Mus., Suppl. 27: 1-143

http://dx.doi.org/10.3853/j.0812-7387.27.2001.1334

Anderson and White, 2001, Rec. Aust. Mus., Suppl. 27: 1-9

http://dx.doi.org/10.3853/j.0812-7387.27.2001.1335

Anderson et al., 2001, Rec. Aust. Mus., Suppl. 27: 11-32

http://dx.doi.org/10.3853/j.0812-7387.27.2001.1336

Anderson et al., 2001, Rec. Aust. Mus., Suppl. 27: 33-42

http://dx.doi.org/10.3853/j.0812-7387.27.2001.1337

Anderson and Green, 2001, Rec. Aust. Mus., Suppl. 27: 43-51

http://dx.doi.org/10.3853/j.0812-7387.27.2001.1338

Marianne et al., 2001, Rec. Aust. Mus., Suppl. 27: 53-66

http://dx.doi.org/10.3853/j.0812-7387.27.2001.1339

Schmidt et al., 2001, Rec. Aust. Mus., Suppl. 27: 67-74

http://dx.doi.org/10.3853/j.0812-7387.27.2001.1340

Smith et al., 2001, Rec. Aust. Mus., Suppl. 27: 75-79

http://dx.doi.org/10.3853/j.0812-7387.27.2001.1341

Matisoo-Smith et al., 2001, Rec. Aust. Mus., Suppl. 27: 81-84

http://dx.doi.org/10.3853/j.0812-7387.27.2001.1342

Holdaway and Anderson, 2001, Rec. Aust. Mus., Suppl. 27: 85-100

http://dx.doi.org/10.3853/j.0812-7387.27.2001.1343

Walter and Anderson, 2001, Rec. Aust. Mus., Suppl. 27: 101-108

http://dx.doi.org/10.3853/j.0812-7387.27.2001.1344

Campbell and Schmidt, 2001, Rec. Aust. Mus., Suppl. 27: 109-114

http://dx.doi.org/10.3853/j.0812-7387.27.2001.1345

Neuweger et al., 2001, Rec. Aust. Mus., Suppl. 27: 115-122

http://dx.doi.org/10.3853/j.0812-7387.27.2001.1346

Macphail et al., 2001, Rec. Aust. Mus., Suppl. 27: 123-134

http://dx.doi.org/10.3853/j.0812-7387.27.2001.1347

Anderson and White, 2001, Rec. Aust. Mus., Suppl. 27: 135-141

http://dx.doi.org/10.3853/j.0812-7387.27.2001.1348 